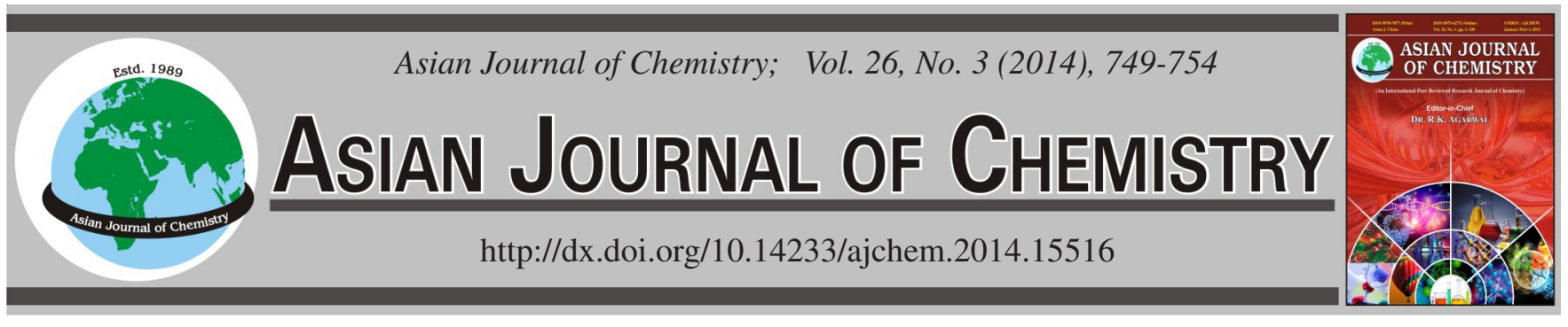

\title{
Synthesis of Some Novel Thiobarbituric Acid Derivatives and Their Related Compounds from Sulfa-Drug as Antiinflammatory
}

\author{
Mohie Aldin M. ZAYED
}

Department of Chemistry, Faculty of Science, King Abdulaziz University, P.O. Box 80203, Jeddah 21589, Saudi Arabia

Corresponding author: Fax: +966 2 6952292; E-mail: mohiem@yahoo.com

Received: 21 March 2013;

Accepted: 26 April 2013;

Published online: 30 January 2014;

AJC-14628

In search for new antiinflammatory agents, some new substituted thiobarbituric acids (2) and their bis-fused or fused thiopyrimidinylpyrimidinone $(\mathbf{7}, \mathbf{8})$ have been derived from sulfathiazole and dimethylmalonate with $\mathrm{CS}_{2}$. structures of the synthesized compounds were established by spectroscopic (FT-IR, ${ }^{1} \mathrm{H}$ NMR, ${ }^{13} \mathrm{C}$ NMR, Mass) and elemental analyses. The antiinflammatory activity of these compounds was tested against carrageen-induced oedema with the reference of standard drug phenyl butazone. The results showed that compounds 2 and $\mathbf{3}$ are better antiinflammatory agents as compared to standard drug phenyl butazone.

Keywords: Synthetic, Thiobarbituric, Antiinflammatory.

\section{INTRODUCTION}

Certain natural and synthetic 1,3-diketo-amine structural analogues have attracted special interest by virture of their varied and pharmaceutically useful biological actions as antimicrobial, anticancer and anti HIV agents ${ }^{1-4}$. Also, several cyclic derivatives containing diketo moiety and -NCSN- linkage are well known for their demonstrable therapeutic efficacy ${ }^{5-8}$. As well as, 1,3-diketoamine analogues forms easily a macrocyclic complexes with nickel(II) as catalytic and antimicrobial aspects, in addition have a metalloenzyme reactions ${ }^{9}$. AbdelRahman et $a l^{10}$ synthetic 1, 3-disubstituted thiobarbituric acids, were showed anti HIV and anticancer activities especially towards leukemia, non-small cell lung, colon cancer and melanoma and recorded a highly per cent of control towards uninfected cells.

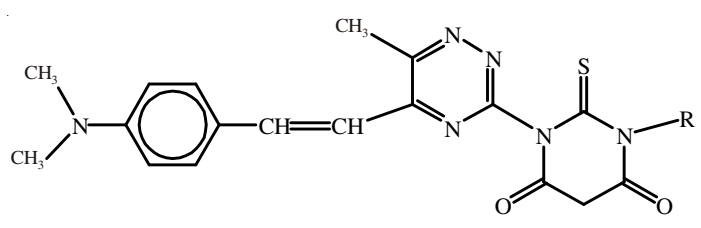

$\mathrm{R}=\mathrm{COCH}_{3}, \mathrm{Ph}$ anti: HIV \& anticancer

Thus, in continuation with our current interest in biocidal heterocyclic systems ${ }^{11-15}$, the present work deals with synthetic strategy of some new 1,3-diketoamine for building a type of thiobarbituric acids and their fused and isolated bis-analogues as biocidal agents.

\section{EXPERIMENTAL}

Melting points were determined with an electro thermal bib by Stuart Scientific Melting Points SMPI (UK). The IR spectra were recorded for $\mathrm{KBr}$ discs on Perkins lemer Spectrum RXI FT-IR System 55529. ${ }^{1} \mathrm{H}$ and ${ }^{13} \mathrm{C}$ NMR spectra were determined for solution in deuterated (DMSO) with a Brucker NMR Advance DPX $400 \mathrm{MH}$ using TMS as an internal standard spectrometer. Electronic absorption spectra were recorded on Shimadzu UV (DMF) and visible 3101 PC spectrophotometer. Molecular weight determination and elemental analysis were preformed by Microanalytical Center Cairo University Egypt. MS were recorded on a gas chromatographic GCMS qp 1000 ex Schimadzu instrument at $70 \mathrm{eV}$.

Preparation of 1,3-diketoamine compound (1): To preheated dimethyl malonate $(0.01 \mathrm{~mol})$, sulfa thiazole $(0.02 \mathrm{~mol})$ were added then warmed for 10-15 min, cooled. The obtained solid was washed with ether then dried crystallized from THF to give compound 1 m.p. $180{ }^{\circ} \mathrm{C}$.

IR $\left(\mathrm{KBr}, \mathrm{v}_{\max }, \mathrm{cm}^{-1}\right): 3560(\mathrm{OH}), 3400(\mathrm{NH}), 1600,1650$ $(2 \mathrm{C}=\mathrm{O}) 2870,1480$ (str. \& bending $\left.\mathrm{CH}_{2}\right), 1370,1355$ $\left(\mathrm{SO}_{2} \mathrm{NH}\right) ;{ }^{1} \mathrm{H} \mathrm{NMR}\left(\mathrm{DMSO}-d_{6}\right): \delta 8.55\left(1 \mathrm{H}, \mathrm{NH}_{-} \mathrm{SO}_{2^{-}}\right), 7.9$ $\left(\mathrm{s}, 1 \mathrm{H}\right.$ of $\left.\mathrm{NH}^{\mathrm{a}}\right), 7.2\left(\mathrm{~s}, 1 \mathrm{H}\right.$ of $\left.\mathrm{NH}^{\mathrm{b}}\right), 5.2(\mathrm{~s}, 1 \mathrm{H}, \mathrm{OH}$ of $\mathrm{HO}-\stackrel{\mathrm{C}}{\mathrm{C}}=\mathrm{C}-\stackrel{\mathrm{C}}{\mathrm{C}}=\mathrm{O} 4.2\left(\mathrm{~d}, 2 \mathrm{H},-\mathrm{CH}_{2}\right), 8.2-7.3(\mathrm{~m}, 12 \mathrm{H}$, of thiazole and aryl protons) ppm; UV (DMF), $\lambda_{\max } 246 \mathrm{~nm}$ $\left(\mathrm{n}-\sigma^{*} \& \pi-\pi^{*}\right)$; MS: $508\left(\mathrm{M}-\mathrm{C}_{3} \mathrm{H}_{2} \mathrm{O}_{2}, 32.11 \%\right), 92\left(\mathrm{C}_{6} \mathrm{H}_{6} \mathrm{~N}\right.$, $11.85 \%), 84$ (thiazole ions $100 \%$ ); Elemental analysis: Found: 
C, 43.16; H, 3.07; N, 14.38; S, $22.07 \%$. Calculated for $\mathrm{C}_{21} \mathrm{H}_{18} \mathrm{~N}_{6} \mathrm{O}_{6} \mathrm{~S}_{4}, \mathrm{C}, 43.59 ; \mathrm{H}, 3.11 ; \mathrm{N}, 14.53 ; \mathrm{S}, 22.14 \%$.

Synthesis of 1,3-diaryl-thiobarbituric acid (2): A mixture of compound 1 (0.01 mol), $\mathrm{CS}_{2}(30 \mathrm{ml})$, DMF $(50 \mathrm{~mL})$ were refluxed for $6 \mathrm{~h}$, cooled then poured onto ice. The produced solid was washed with cold ethanol and crystallized from $\mathrm{MeOH}$ to give 2 m.p. $130{ }^{\circ} \mathrm{C}$. IR ( KBr, $\left.\nu_{\max }, \mathrm{cm}^{-1}\right): 3100-2850$ (b, aromatic \& aliphatic $\mathrm{CH}), 1710,1670(2 \mathrm{C}=\mathrm{O}) 1350$ $\left(\mathrm{SO}_{2} \mathrm{NH}\right), 1180(\mathrm{C}-\mathrm{S}) \mathrm{cm}^{-1} ;{ }^{1} \mathrm{H}$ NMR (DMSO- $\left.d_{6}\right): \delta 8.8(\mathrm{~s}$, $1 \mathrm{H}, \mathrm{OH}), 8.5(\mathrm{~s}, 1 \mathrm{H}$, cyclic $-\mathrm{CH}=)$, 8.2-7.3 (m, $12 \mathrm{H}$, thiazole, $\&$ aryl protons) $\mathrm{ppm} ;{ }^{13} \mathrm{C} \mathrm{NMR}(\delta): 185.1(\mathrm{C}=\mathrm{S}), 159.7(\mathrm{C}=\mathrm{lO})$, $27.5\left(\underline{\mathrm{CH}}_{2}-\mathrm{CO}\right), 142(\mathrm{C}-\mathrm{N}-\mathrm{C}), 148.1\left(\underline{\mathrm{C}-\mathrm{S}-}{ }^{12} \mathrm{C}\right), 156.8(\mathrm{~N}-\underline{\mathrm{C}}-$ $\mathrm{S}), 133.3\left(\mathrm{C}_{6}-\mathrm{SO}_{2}\right), 131.36\left(\mathrm{C}_{1}-\mathrm{N}\right), 130.15,129.3,128.5,127.2$ (4C of aryl). UV (DMF), $\lambda_{\max } 286 \mathrm{~nm}$; MS: $620\left(\mathrm{M}^{+}, 5.1\right), 576$ (3.2), 520 (1.85), 293 (75.5), 155 (43.1), 84 (100\%). Found: $\mathrm{C}, 42.19 ; \mathrm{H}, 2.54 ; \mathrm{N}, 13.17 ; \mathrm{S}, 9.70 \%$. Calculated for $\mathrm{C}_{22} \mathrm{H}_{16} \mathrm{~N}_{6} \mathrm{~S}_{5} \mathrm{O}_{6} ; \mathrm{C}, 42.28 ; \mathrm{H}, 2.58 ; \mathrm{N}, 13.54 ; \mathrm{S}, 9.92 \%$.

Synthesis of bis-fused Pyrido thiobarbituric acid (3): A mixture of compound 2 (0.02 mol), 2-chloro-6-fluorobenzaldehyde $(0.01 \mathrm{~mol})$, ammonium acetate $(0.01 \mathrm{~mol})$ with few drops of glacial acetic acid was fused under reflux for $4 \mathrm{~h}$, cooled then poured onto ice. The yielded solid was filtered off and crystallized from DMF to give 3 m.p. $160^{\circ} \mathrm{C}$. IR ( $\mathrm{KBr}$, $\left.\mathrm{V}_{\max }, \mathrm{cm}^{-1}\right): 3140(\mathrm{NH}), 1710(\mathrm{C}=\mathrm{O}), 1380(\mathrm{NCSN}), 1180$ (C-S), 3010, 870 (aryl carbon), $450(\mathrm{C}-\mathrm{F}) \mathrm{cm}^{-1}$; ${ }^{1} \mathrm{H}$ NMR (DMSO- $d_{6}$ ): $\delta 8.2,6.8$ (each s, $\mathrm{NH}, \mathrm{CH}$, of pyridine), 7.9-7.6 ( $\mathrm{m}, 12 \mathrm{H}$, thiazole $\&$ aryl protons), 7.5-7.2 (m, 3H of difluorochlorophenyl) ppm; UV (DMF), $\lambda_{\max } 320 \mathrm{~nm}$. Found: C, 44.65; H, 2.30; N, 13.22; S, 23.22\%. Calculated for $\mathrm{C}_{51} \mathrm{H}_{32} \mathrm{~N}_{13} \mathrm{O}_{10} \mathrm{~S}_{10} \mathrm{ClF}$; C, 45.00; H, 2.85; N, 13.38; S, $23.52 \%$.

Trifluoroacetyl thiobarbituric acid derivative (4): A mixture of compound $\mathbf{2}(2 \mathrm{~g})$ and trifluoro acetic acid $(5 \mathrm{~mL})$ in THF $(50 \mathrm{~mL})$ was refluxed for $2 \mathrm{~h}$, cooled then poured onto ice. The solid obtained filtered off and crystallized from EtOH to give 4 m.p. $175^{\circ} \mathrm{C}$.

IR $\left(\mathrm{KBr}, v_{\max }, \mathrm{cm}^{-1}\right): 1710,1680,1650(3 \mathrm{C}=\mathrm{O}), 1200$ (C-F), $1330\left(\mathrm{NH}_{-} \mathrm{SO}_{2^{-}}\right.$), 1180 (C-S), 3000 \& 820 (str. \& bending aryl) $\mathrm{cm}^{-1} ;{ }^{1} \mathrm{H}$ NMR (DMSO- $\left.d_{6}\right): \delta 8.1,7.2(\mathrm{~m}, 12 \mathrm{H}$, thiazole \& aryl protons), $8.2\left(\mathrm{~s}, 1 \mathrm{H}, \mathrm{SO}_{2} \mathrm{NH}\right), 3.8\left(\mathrm{~s}, 1 \mathrm{H}, \mathrm{H}_{-} \mathrm{C}_{5} \mathrm{CO}\right)$ ppm; Found, C, 39.82; H, 2.06; N, 11.57; S, $21.89 \%$. Calculated for $\mathrm{C}_{24} \mathrm{H}_{15} \mathrm{~N}_{6} \mathrm{O}_{7} \mathrm{~S}_{5} \mathrm{~F}_{3} ; \mathrm{C}, 40.22 ; \mathrm{H}, 2.09 ; \mathrm{N}, 11.73 ; \mathrm{S}$, $22.34 \%$.

Formation of 5-disubstituted methyl- $\mathbf{N}^{1}, \mathbf{N}^{3}$-diaryl-2thioxo-pyrimidin-4,6-diones ( 5 \& 6): A mixture of compound $2(0.01 \mathrm{~mol})$ and 3-chloroacetyl acetone or ethyl 2-chloroacetoacetate $(0.01 \mathrm{~mol})$ in DMF $(50 \mathrm{~mL})$ was refluxed for $1 \mathrm{~h}$, cooled then poured onto ice. The produced solid was filtered off and crystallized dioxane to give 5 and $\mathbf{6}$ from THF. 5 m.p. 202, 6 m.p. $285^{\circ} \mathrm{C}$.

IR (KBr, $\left.v_{\max }, \mathrm{cm}^{-1}\right): 1720,1710$, (exocyclic $\left.2 \mathrm{C}=\mathrm{O}\right), 1680$, 1660 (endocyclic $2 \mathrm{C}=\mathrm{O}$ ) $\mathrm{cm}^{-1}$. Found (5): C, 44.47; H, 3.14; N, 11.08; S, $21.11 \%$. Calculated for $\mathrm{C}_{28} \mathrm{H}_{24} \mathrm{~N}_{6} \mathrm{~S}_{5} \mathrm{O}_{9} ; \mathrm{C}, 44.98$; H, 3.20; N, 11.22; S, $21.39 \%$. Found (6): C, 44.53; H, 3.02; $\mathrm{N}, 11.35 ; \mathrm{S}, 21.83 \%$. Calculated for $\mathrm{C}_{27} \mathrm{H}_{22} \mathrm{~N}_{6} \mathrm{~S}_{5} \mathrm{O}_{8} ; \mathrm{C}, 45.12$; H, 3.06; N, 11.69; S, $22.28 \%$.

Synthesis of 2-thioxo-4-methyl-5,6-dihydro-5-(1,3diaryl-4,6-dioxo-5H-pyrimidin-5-yl)pyrimidin-6(1H)one (7) and 4,6-dimethyl-2-thioxo-5-(1,3-diaryl-4,6-dioxo-
$5 \boldsymbol{H}$-pyrimidin-5yl)pyrimidine (8): Equimolar mixture of compound $\mathbf{2}$ and ethyl 2-chloroacetoacetate or 3-chloroacetylacetone and thiourea in sodium ethoxide $(0.02 \mathrm{~mol}, 50 \mathrm{~mL})$ was refluxed for $4 \mathrm{~h}$ and cooled then pourd onto ice-HCl. The obtained solid was filtered off and washed with cold water and crystallized from EtOH to give $\mathbf{7}$ and $\mathbf{8}$, respectively $\mathbf{7}$ m.p. $221^{\circ} \mathrm{C} ; 8$ m.p $265^{\circ} \mathrm{C}$.

IR $\left(\mathrm{KBr}, v_{\max }, \mathrm{cm}^{-1}\right): 3120(\mathrm{NH}), 3000,2980,2870$ (aromatic \& aliphatic $\mathrm{CH}), 1700,1680,1660 \& 1650(4 \mathrm{C}=\mathrm{O})$, $1580(\mathrm{C}=\mathrm{N}), 1350(\mathrm{NCSN}), 1480,1440$ (deformation Me), $1180(\mathrm{C}-\mathrm{S}) \mathrm{cm}^{-1} .{ }^{1} \mathrm{H}$ NMR (DMSO-d $): 7: \delta 8.15(\mathrm{~s}, 1 \mathrm{H}, \mathrm{NH})$, $7.9(\mathrm{~s}, 1 \mathrm{H}$, cyclic $\mathrm{HC}=\mathrm{C}-), 7.7-7.2(\mathrm{~m}, 12 \mathrm{H}$, aromatic \& thiazole protons), $4.1 \& 3.8$ (each $\mathrm{s}, 2 \mathrm{H}$, of $\mathrm{H}^{\alpha} \& \mathrm{H}^{\beta}$ of pyridine), 1.1 (s, 3H, $\left.\mathrm{CH}_{3}\right), 8: \delta 8.2(\mathrm{~s}, 1 \mathrm{H}, \mathrm{NH}), 7.8(\mathrm{~s}, 1 \mathrm{H}$, cyclic $\mathrm{HC}=\mathrm{C}-)$, 7.6-7.15 (m, 12H, aromatic \& thiazole protons), 4.1 (s, $1 \mathrm{H}$, of $\mathrm{H}^{\alpha}$ of pyridine), $1.5 \& 1.2$ (s, two $\mathrm{CH}_{3}$ ) ppm. UV (DMF): 7 $\lambda_{\max } 286,8 \lambda_{\max } 315 \mathrm{~nm}$. Found (\%) 7: C, 41.87; H, 2.57; N, 14.53; S, 24.93. Calcd. (\%) for $\mathrm{C}_{27} \mathrm{H}_{20} \mathrm{~N}_{8} \mathrm{O}_{7} \mathrm{~S}_{6} \mathrm{C}, 42.63 ; \mathrm{H}$, 2.63; N, 14.73; S, 25.26. Found (\%) 8: C, 43.75; H, 2.84; N, 14.58; S, 24.84. Calcd. (\%) for $\mathrm{C}_{28} \mathrm{H}_{22} \mathrm{~N}_{8} \mathrm{~S}_{6} \mathrm{O}_{6} \mathrm{C}, 44.32 ; \mathrm{H}$, $2.90 ; \mathrm{N}, 14.77 ; \mathrm{S}, 25.32$.

\section{RESULTS AND DISCUSSION}

Heterocyclic ring plays an important role in biochemical processes because the side groups of the most typical and essential constituents of the living cells, DNA and RNA are based on aromatic heterocycles ${ }^{16}$. Thus, a main aim of the present work is to synthesize pyrimidinone as targets via warming of preheated dimethyl malonate with sulfathiazole (1:2 by mole) in dry conditions ${ }^{17}$ to produce 1,3 -diketoamine $\mathbf{1}$. Heterocyclization of compound 1 by refluxing with $\mathrm{CS}_{2}$ in $\mathrm{DMF}^{18}$ afforded 1,3-diarylthiobarbituric acid (2). Also, 6-aryl-1,4dihydro-2,4,8,10-tetraaryl-3,9-dithioxo-pyrido[2,3-d: 6,5-d]dipyrimidin-5,7-dione (3) was obtained from refluxing 2 with 2-chloro-6-fluorobenzaldehyde ( $2: 1$ by mole) in ammonium acetate-glacial acetic acid (Scheme-I). Formation of $\mathbf{3}$ from $\mathbf{2}$ can be outlined in Scheme-II.

Presence of $\alpha$-active proton of methylene group ${ }^{19}$ containing compound $\mathbf{2}$ was deduced from acylation using trifluoroacetic acid in boiling THF to give 5-trifluoroacetyl-1,3-diaryl2-thioxopyrimidin-4,6-(5H) dione (4) (Scheme-III).

It is interesting that a simple alkylation of $\alpha$-active proton of compound $\mathbf{2}$ via a nucleophilic attack to labile chlorine atom containing $\alpha$-halo alkylating agents ${ }^{20,21}$ such as ethyl-2-chloroacetoacetate and/or 3-chloro acetyl acetone as $\mathrm{SN}^{2}$ reactions in boiling DMF as basic-catalyzed to produce a type of 5-alkyl derivatives 5 and $\mathbf{6}$ respectively (Scheme-III).

Finally, ring closure reactions of 1,3-bioxocompounds 5 and $\mathbf{6}$ by refluxing with thiourea in sodium ethoxide solution afforded the thioxo pyrimidin-5-yl-pyrimidinone derivatives $\mathbf{7}$ and $\mathbf{8}$ respectively (Scheme-III). Formation of compound $\mathbf{8}$ from 2 may be takes place as shown in Scheme-IV.

Studies on static polarizabilities and hyper polarizabilities have been performed extensively with increasing importance of molecular orbitals calculation. Thus, a possible solubility of the prepared compounds with sodium hydroxide solution can be a good tool for obtaining some insight into molecular property and as a result of tautomeric forms, in establishing 


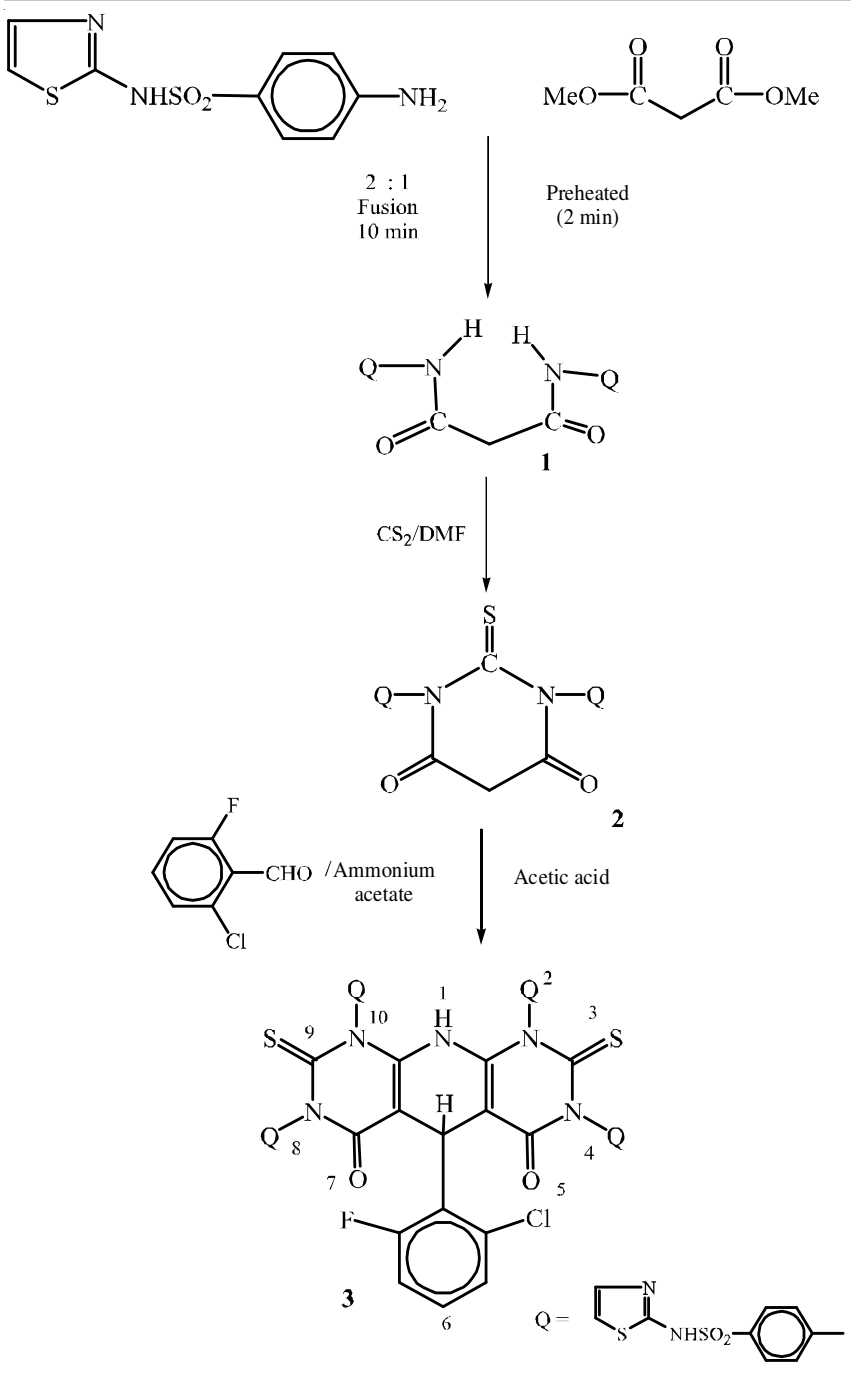

Scheme-I

the structure property relationship. In the present study, the obtained systems $\mathbf{2 - 8}$ reported a free solubilities with sodium hydroxide solution, which indicates that a higher polarization of ketonic $\rightleftharpoons$ enolic functional groups of these systems and give additional physico-chemical property, as easily electronic mobilities over molecular centers.

Structures of obtained compounds 1-8 have been established from their molecular weight determination and spectral data.

Compound 1 showed characteristic IR absorption bands in the region of $3560(\mathrm{OH}), 3400(\mathrm{NH}), 1700,1650(\mathrm{C}=\mathrm{O}$, 1,3-diketone, $\left.\mathrm{COCH}=\mathrm{CH}-\mathrm{OH} \rightleftharpoons-\mathrm{COCH}_{2} \mathrm{CO}-\right), 1370$ $1355 \mathrm{~cm}^{-1}\left(\mathrm{SO}_{2} \mathrm{NH}\right) .{ }^{1} \mathrm{H}$ NMR spectrum of 1 showed characteristic resonance signals at $\delta 8.55\left(\mathrm{SO}_{2} \mathrm{NH}\right), \delta 7.9\left(\mathrm{NH}^{\mathrm{b}}\right), 7.2$ $\left(\mathrm{NH}^{\mathrm{a}}\right), 5.2(\mathrm{OH}), 4.2\left(2 \mathrm{H}, \mathrm{CH}_{2}\right)$ in additional the thiazole and aromatic protons at $\delta$ 7.2-8.2 ppm.

Compound 2 recorded the lacks of $\mathrm{NH}$ absorption bands in IR spectrum. Also, exhibited resonance signals corresponding to $\mathrm{CO} \underline{\mathrm{CH}}_{2} \mathrm{CO}$ at $\delta 4.2$ besides the thiazole and aromatic protons at 8.2-7.3 ppm. UV absorption spectrum recorded $\lambda_{\max }$ $286 \mathrm{~nm}$ while M/S spectroscopy recorded the molecular ion peak at $m / z, 620$ which under went further fragmentation process gave the thiazole ion as base peak $\mathrm{m} / \mathrm{z}, 84(100 \%)$ (Scheme-V).

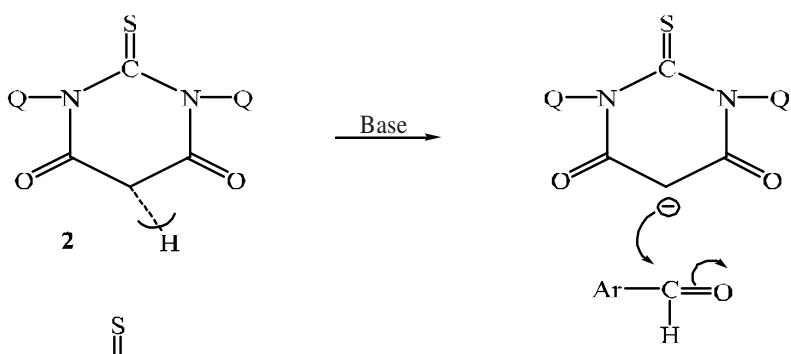<smiles>C=C1C(=O)N([O])C(=S)N(O)C1=O</smiles><smiles>CC[13CH]=C1C(=O)N([O-])C(=S)N([O-])C1=O</smiles><smiles>CCC(O)C1C(=O)N(O)C(=S)N([AlH])C1=O</smiles>

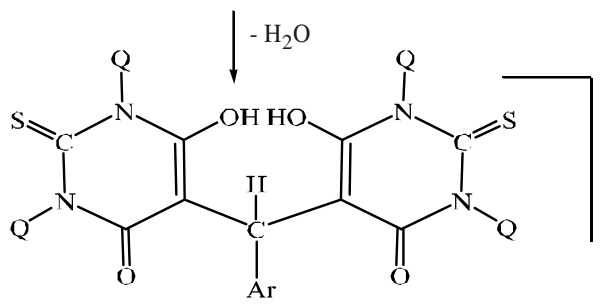<smiles>CCCCCCCCCCCC(N)=O</smiles>

3

Scheme-II

The structure of compound $\mathbf{3}$ assignment based on off ${ }^{1} \mathrm{H}$ NMR spectra which showed a resonance signals at $\delta 8.2$ and $6.8 \mathrm{ppm}(\mathrm{NH}, \mathrm{CH}$ of pyridine in addition at 7.2-7.5 ppm $(3 \mathrm{H}$ of dihalogen aryl protons). IR spectrum of 3 recorded $n$ at $3140(\mathrm{NH}), 1710(\mathrm{C}=\mathrm{O}), 1380(\mathrm{NCSN}), 1180(\mathrm{C}-\mathrm{S})$ and 1150 (C-F). UV absorption spectrum of $\mathbf{3}$ give a good indication about a polyelectronic transition by showed $\lambda_{\max } 320 \mathrm{nmin}$ compare with 2 at $286 \mathrm{~nm}$.

On the other hand, structure of $\mathbf{4}$ deduced from its ${ }^{1} \mathrm{H}$ NMR spectrum which showed a resonated signals at $\delta 3.8$ ( $1 \mathrm{H}$ of $\mathrm{HC}_{5}-\mathrm{COCF}_{3}$ of pyrimidindione), $8.2\left(1 \mathrm{H}, \mathrm{SO}_{2} \mathrm{NH}\right)$, in addition of thiazole and aromatic protons at $\delta$ 8.1-7.2 ppm. 


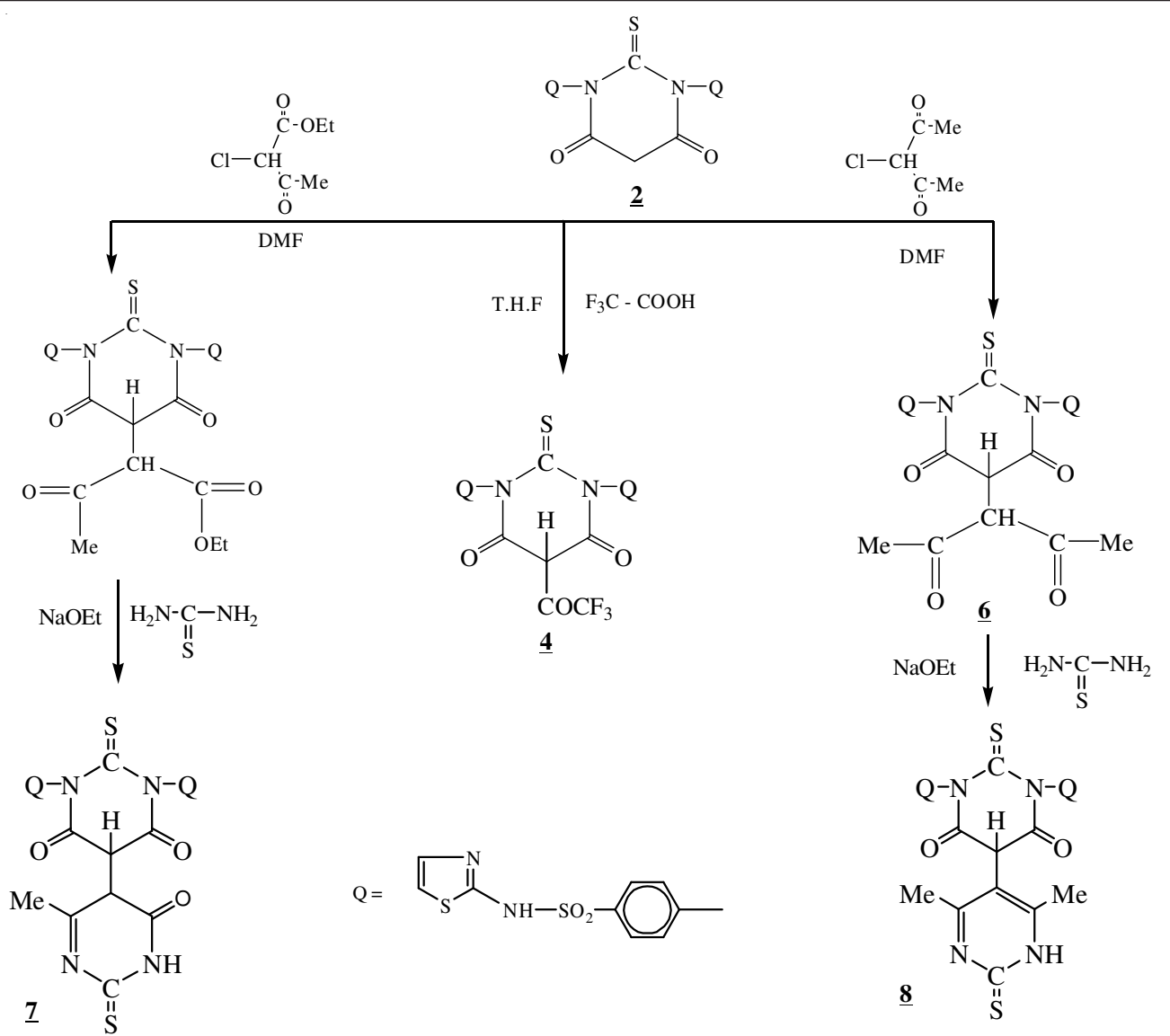

Scheme-III

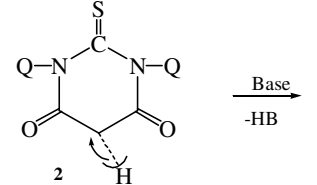

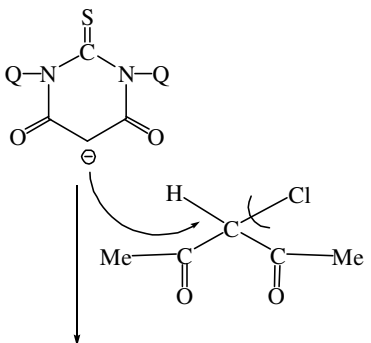<smiles></smiles><smiles>CC(O)C(C(C)O)C1C(=O)N(O)C(=S)N(O)C1=O</smiles><smiles>NC(N)=S</smiles>

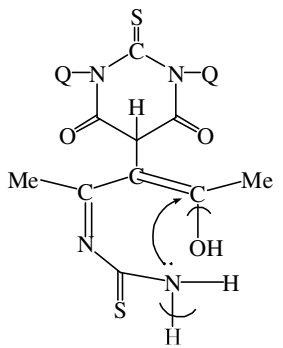<smiles>C[13CH]I</smiles><smiles></smiles>

Scheme-IV: Formation of compound $\mathbf{8}$ from $\mathbf{2}$
The differential structures between compounds $\mathbf{7}$ and $\mathbf{8}$ was concerted in : $\mathrm{H}^{\alpha}$ and $\mathrm{H}^{\beta}$ of two pyrimidine rings at 3.8 and $4.1 \mathrm{ppm}$ of compound 7 while that showed only $\mathrm{H}^{\alpha}$ in the compound $\mathbf{8}$. Also, compound $\mathbf{8}$ recorded two signals of two methyl groups at 1.2 and $1.5 \mathrm{ppm}$ while that of 7 exhibited only one methyl group at $1.1 \mathrm{ppm}$. Both the compounds 7 and 8 recovered the resonated signals at 8.2 due to $\mathrm{NH}$ protons of pyrimidindione. Finally, UV absorption spectra indicated that $\lambda_{\max }$ of compound $\mathbf{8}$ is more than that of $7, \lambda_{\max }$ of $\mathbf{8}$ at 315 while that of 7 at $280 \mathrm{~nm}$.

IR spectra study of all obtained compounds in both the solid states and their solution states $\left(\mathrm{CHCl}_{3}\right.$ as solvent on cold showed that lacks of $\mathrm{OH}, \mathrm{NH}$ and or $\mathrm{SH}$ functional groups in the solution states. These results confirm that these targets have a higher possibilities to acidic character which enhanced their biocidal efforts.

Pharmacology: In recent years, human pathogenic microorganisms have developed resistance in response to the indiscriminate use of commercial antimicrobial drugs commonly employed in the treatment of infectious diseases. The discovery of mefenamic acid and meclofenamate ${ }^{22}$ as useful agents for clinical treatment of inflammatory disorders has led to the exploration of anthranilic acid, with the aim to obtain better antiinflammatory agents.

Thus, the newly synthesized compounds were studied for their antiinflammatory activity against carrageean-induced oedema. All the compounds were tested with a dose of $50 \mathrm{mg} / \mathrm{kg}$ given orally following the reported technique ${ }^{22-24}$ (Table-1). 

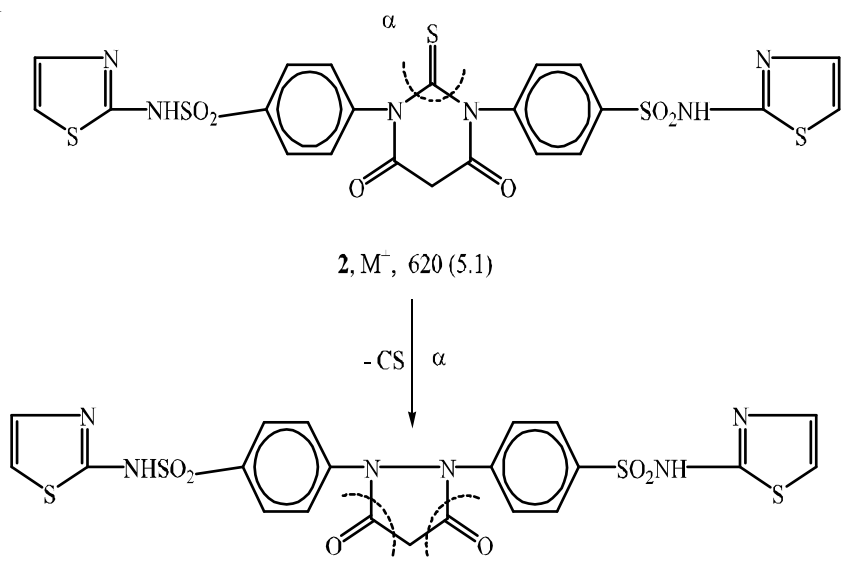

$$
576(3.2)
$$
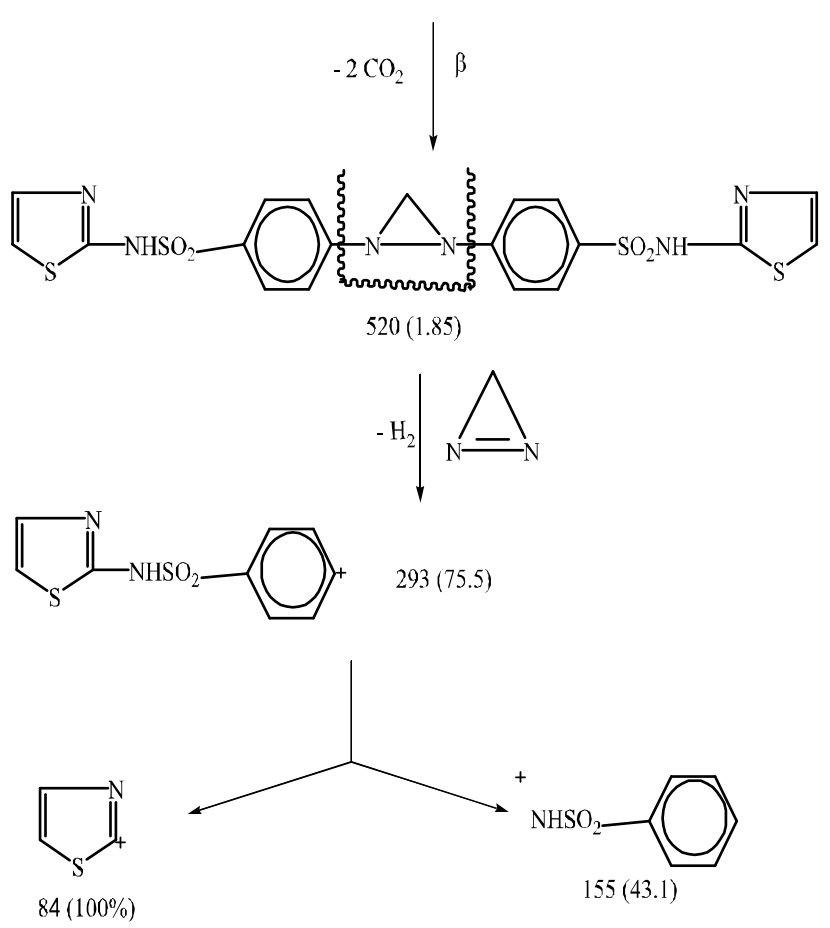

Scheme-V: Mass fragmentation pattern of compound 2

\begin{tabular}{|c|c|c|c|}
\hline \multicolumn{4}{|c|}{$\begin{array}{l}\text { TABLE-1 } \\
\text { EFFECT OF NEW SYNTHESIZED COMPOUNDS ON } \\
\text { CARRAGEENAN-INDUCED PAW EDEMA IN RATS }\end{array}$} \\
\hline Compd. No. & $\begin{array}{c}\text { Dose } \\
(\mathrm{mg} / \mathrm{kg})\end{array}$ & $\begin{array}{l}\text { Paw edema (1) } \\
\text { + S.E. }\end{array}$ & $\begin{array}{l}\text { Inhibition } \\
(\%)\end{array}$ \\
\hline \multirow[t]{2}{*}{2} & 25 & $0.20 \pm 0.01^{*}$ & 69.62 \\
\hline & 5 & $0.20 \pm 0.01^{*}$ & 54.54 \\
\hline \multirow[t]{2}{*}{3} & 25 & $0.36 \pm 0.03^{*}$ & 45.45 \\
\hline & 5 & $0.50 \pm 0.03^{*}$ & 24.24 \\
\hline \multirow[t]{2}{*}{4} & 25 & $0.36 \pm 0.03^{*}$ & 45.45 \\
\hline & 5 & $0.40 \pm 0.06^{*}$ & 39.39 \\
\hline \multirow[t]{2}{*}{ Control phenyl butazone } & 25 & $0.66 \pm 0.05^{*}$ & 40.40 \\
\hline & 5 & $0.32 \pm 0.02^{*}$ & \\
\hline
\end{tabular}

After $1 \mathrm{~h}$, the drug administration, induction of inflammation in the kinds paw which performed by sub cultaneous (S.C) injection of $50 \mu \mathrm{L}$ of $1 \%$ carrageenan sodium gel into the subplantar region. After $3 \mathrm{~h}$, the induction of inflammation, the animals were sacrificed. Both the hind paws of each animal were cut and weighed. The difference between weight of the right kind paw and the left paw of each animal was taken as a measure of edema. The \% inhibition of inflammation was calculated according to:

Inhibition $(\%)=\frac{\text { wt. of paw edema of control - wt. of paw edema filteraled }}{\text { wt. of pawedema of control }}$

It is interesting to point out that all compounds showed antiinflammatory activity within moderate to lethal activities. Compounds $\mathbf{2}$ and $\mathbf{3}$ exhibited a high potency and dosedependent anti-inflammatory activity a maximum activity $69.62,54.54$ of $\mathbf{2}$ and of $\mathbf{3}$ at $45.45,24.2450 \mathrm{mg} / \mathrm{kg}$, in compare with the standard drug (phenyl butazone). QSAR showed that methane group between two carbonyl led to a highly acidic character of compound $\mathbf{2}$ as well as presence of fluorine and chlorine atoms (highly electronegative) at positions 2 and the phenyl ring caused the enhanced anti inflammatory activity ${ }^{25,26}$. Also, at lower sulfur (\%) of the tested compounds exhibited a higher inhibition $(\%)^{27}$.

\section{Conclusions}

This article presented the synthesis and characterization of novel thiobarbituric acids and their bis-fused/isolated analogues based on heterocyclization of 1,3-diketoamine with $\alpha, \beta$-bi-functional reagents. The evaluation of these compounds as anti-inflammatory agents provides the following trends:

(i) Compounds $\mathbf{2}$ and $\mathbf{3}$ exhibited a highly effects in compare with control phenyl butazone, while other tested compounds recorded a lethal effects as antiinflammatory activity.

(ii) At lower sulfur (\%) of the tested compounds exhibited a higher inhibition (\%) as antiinflammatory agents.

(iii) A higher effects of compounds $\mathbf{2}$ and $\mathbf{3}$ is mainly due to presence of fluorine and chloride atoms beside of a sulfa moiety $^{26-29}$.

\section{ACKNOWLEDGEMENTS}

The authors are thankful to Prof. Dr. Z. El-Baza, Department of Pharmaceutical Microbiology, National Center for Radiation Research and Technology, Nasr City, Egypt for antiinflammatory evaluation.

\section{REFERENCES}

1. A. De Logu, V. Omis, B. Saddi, C. Congien and M.L. Schivo, J. Antimicrob. Chemother, 49, 275 (2002).

2. L. Savini, L. Chiasserini, A. Gaeta and C. Pellerano, Bioorg. Med. Chem., 10, 2193 (2002).

3. A.M. Asiri and S.A. Khan, Molecules, 15, 4784 (2010).

4. A. Andreani, M. Granaiola, A. Lemi, A. Locatelli, R. Morigi, M. Rambaldi, G. Giorgi and V. Garaliene, Anticancer Res., 24, 203 (2004).

5. M.E. Furrow and A.G. Myers, J. Am. Chem. Soc., 126, 5436 (2004).

6. S.A. Khan, N. Singh and K. Saleem, Eur. J. Med. Chem., 43, 2272 (2008).

7. G.R. Cook, B.C. Maity and R. Kargbo, Org. Lett., 6, 1741 (2004).

8. A.K. Halve, P. Gour, R. Dubey, D. Bhadauria, B. Bhaskari, J. Indian Chem. Soc., 82, 942 (2005).

9. A.M. Asiri and S.A. Khan, Molecules, 16, 523 (2011).

10 R.M. Abdel-Rahman, J.M. Morsy, F. Hanafy and H.A. Amene, Pharmazie, 54, 347 (1999).

11. R.M. Abdel-Rahman, Pharmazie, 56, 18 (2001).

12. R.M. Abdel-Rahman, Pharmazie, 56, 195 (2001).

13. R.M. Abdel-Rahman, Trends Heterocycl. Chem., 8, 187 (2002).

14. W.R. Abdel-Monem and R.M. Abdel-Rahman, Int. J. Chem., 16, 1 (2006). 
15. M.A. Ibrahim, R.M. Abdel-Rahman, A.M. Abdel-Halim, S.S. Ibrahim and H.A. Allimony, ARKIVOC, 202 (2008).

16. M.G. Valverde and T. Torroba, Sulfur-Nitrogen Heterocycl. Mol., 10, 318 (2005).

17. S.M. Abu-El-Wafa, R.M. Abdel-Rahman and Z. El-Gendy, Egypt J. Chem., 33, 387 (1990)

18. J.H. Chern, K.S. Shia, C.M. Chang, C.C. Lee, Y.-C. Lee, C.-L. Tai, Y.T. Lin, C.-S. Chang and H.-Y. Tseng, Bioorg. Med. Chem. Lett., 14, 1169 (2004).

19. M. Seada, R. M. Abdel-Rahman and M. Abdel-Megib, Indian J. Heterocycl. Chem., 3, 9 (1993).

20. T.E. Ali, R.M. Abdel-Rahman, F.I. Hanafy and S.M. El-Edfawy, Phosphorous Sulfur Silicon Rel. Elem., 183, 2565 (2008).
21. M.A. Ibrahim, R.M. Abdel-Rahman, A.M. Abdel-Halim, S.S. Ibrahim and H.A. Allimony, J. Braz. Chem. Soc., 20, 1275 (2009).

22. C.A. Winter, E.A. Fisely and C.M. Nuss, Exp. Biol. Med., 111, 544 (1962).

23. P. Ashokkumar and G. Sudhandiran, Biomed. Pharmacother., 62, 590 (2008).

24. C.A. Winter, E.A. Risley and G.W. Nuss J. Pharm. Exp. Ther, 141, 369 (1963).

25. R.M. Abdel-Rahman, M.S.T. Makki and W.A. Bawazir, E.J. Chem., 7(Si), 93 (2010).

26. R.M. Abdel-Rahman, M.S.T. Makki and W.A. Bawazir, E.J. Chem., 8, 405 (2011).

27. R.M. Abdel-Rahman, K.O. Al-Footy and F.M. Aglan, Int. J. Chem. Tech. Res., 3, 423 (2011). 